\title{
Analysis of Educational Impact on Women Entrepreneurs in Sustainable Social Business: The Case of Azerbaijan
}

\author{
Fariz Ahmadov ${ }^{1}$, Ulkar Zeynalova ${ }^{2}$, Ulkar Bayramova ${ }^{3}$, Ilkin Mammadov ${ }^{4}$ \\ ${ }^{1}$ Assoc. Prof, Azerbaijan State University of Economic (UNEC), Head of the International Center for \\ Graduate Education \\ Email: f.ahmadov@unec.edu.az \\ ${ }^{2}$ Res. Asst, Azerbaijan State University of Economic (UNEC), Graduate Student of International \\ Graduate Education Center \\ Email: ulker.zeynalova95@gmail.com \\ ${ }^{3}$ Res. Asst, Azerbaijan State University of Economic (UNEC), Graduate Student of International \\ Graduate Education Center \\ Email: ulkerbayramova93@gmail.com \\ ${ }^{4}$ Lecturer, Azerbaijan State University of Economic (UNEC), Economics and Business \\ Administration Department \\ Email: ilkinmammadov@unec.edu.az
}

Article History: Received: 10 November 2020; Revised 12 January 2021 Accepted: 27 January 2021; Published online: 5 April 2021

\begin{abstract}
Education is one of the key factors that influences the definition of entrepreneurial women and helps to realize the potential and awareness of existing entrepreneurship characteristics in women. In today's developing world, it is important that companies and people's approach are very careful in solving social problems. Entrepreneurship is thought to be the most effective tool in increasing its market share. Social business is one of the key solutions to global challenges such as poverty reduction, employment growth and social reintegration. This study, aimed at the sustainability of women entrepreneurs engaged in social activities in Azerbaijan, has examined the effect of education on how well informed women are and the main factors driving them to this field. For this purpose, the entrepreneurship and social management of women were examined theoretically and systematically. The role of education in women entrepreneurship and the effect of education levels and educational activities of women entrepreneurs in the field of social entrepreneurship in Azerbaijan were examined, as well. Finally, proposals were made on the basis of theory, world experience and analysis.
\end{abstract}

Keywords: Social Business, Women Entrepreneurship, Education, Sustainability

\section{Women entrepreneurship}

Women entrepreneurs are regarded as individuals who have a difficult task to be independent economically and meet their personal needs (Dharmendran, 2016: 70). Millions of women around the world are engaged in entrepreneurial activity. It is noteworthy that women-led and owned companies are successful and have a high level of development (Rosenberg, 2007: 15). Participation of women in entrepreneurial activity stimulates other women, creates new ideas in the society, ensures high-level education of future generations. If a woman is engaged in entrepreneurial activity and creates a new job, then the day comes when 
unemployment is reduced, employment opportunities for individuals with physical disabilities (disabled, martyr families, those deprived of family protection, etc.) are difficult to find. The society with developed women and with world vision is considered advanced one. In all economies, female entrepreneurs have a great impact on innovation, employment growth and material opportunities (Brush vd 2009).

There are various reasons for directing towards entrepreneurship, but higher levels of education, family and income play a key role within the each one. In the literature, the desire to carry out their innovative ideas, having the social status and the self-confidence, the desire to support the family, the need for additional income, decision-making freedom and the desire to be independent and the desire for self-realization, ensuring the good future for the children, to be a good example for others, the continuation of family business emphasize that women are directed towards the entrepreneurship. In developing countries, women's participation in the labor force is crucial to ensuring the development of the economy and society (Vita et al., 2014).

In Denmark, the percentage to set a new business by women is $30 \%$ and their selfemployment level is 25\% (Neergaard, 2006). And in Finland, 33\% of all women are selfemployed in entrepreneurial activity (Kovalainen and Arenius, 2006). In Hong Kong, the study revealed that parents being entrepreneur has a positive impact on women's entrepreneurial spirit, and many female entrepreneur's parents are also involved in entrepreneurial activity (Pue Ho Chu, 2004: 172).

Chart 1: Total entrepreneurship percentages

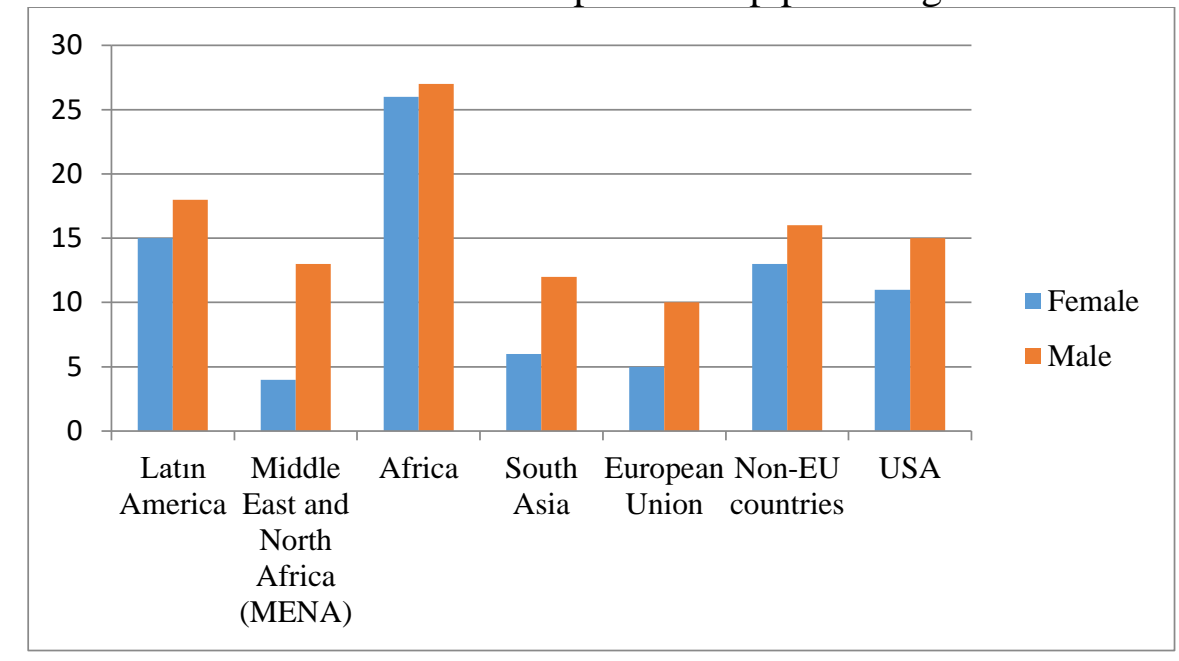

Source: Xavier Vd., 2012, p. 29

Chart 1 shows a significant difference between the male and female entrepreneurs in MENA region and in the European Union. According to the results of the GEM study, the percentage of women to discontinue or completely stop their entrepreneurial activity is less than men (Kelley et al., 2010: 32).

"Entrepreneurship" for women entrepreneurs in Chile, Tunisia, the Netherlands, Columbia, Ghana and Italy means a good career; in countries like Finland, Egypt, Angola, Iran, China, Israel and Greece - high status; in in countries like Saudi Arabia, Taiwan, Brazil, Australia, 
and Malaysia - to be recognized and accepted by society in the surrounding environment. (Kelley et al 2011: 17)

According to 2017 statistical reports, more than 11.6 million companies in the USA belong to women and their total income is \$ 1.7 trillion (State of Women-Owned Businesses Report 2017). Companies owned by women are more than $51 \%$, and it comprises $39 \%$ of private firms and $8 \%$ of employment and $4.2 \%$ of income. One of the five companies with revenue of $\$ 1$ million or more are owned by female entrepreneurs. $4.2 \%$ of all women-owned businesses earn 1 million or more profit (Women Business Owner Statistics 2017).

In general, we see that women's entrepreneurship is at a high level in Canada, and opportunities and chances are created for that. The reasons for having a very good level of women entrepreneurship in the US and Canada are explained by the following factors (Littlejohn, 2006: 109-111):

- Creation of the "Duty Force of Women Entrepreneurs" in the USA in 1972 and the Canadian Presidential Task Force created in Canada in 2002-2003,

- Existence of detailed investigations and regular reports about women's entrepreneurship,

- Support and incentives provided by state to NGOs (Non-Governmental Organizations)

- High level of organization of women entrepreneurship, headed by the International Women's Business Council (NWBC)

- Presence of an international and permanent contact network for women entrepreneurs to provide information, advice and support services,

- Encouraging large-scale investment elements such as micro-credit, bank loans, business fund, and incentive levels,

- Presence of regular rewarding and incentive mechanisms for women entrepreneurs

- Keeping women entrepreneurial role models at the forefront,

- Businesses with women entrepreneurs have a mission to compete in international markets

\section{Women's education level}

Education on entrepreneurship can be specified as the purposeful intervention by an educator in the life of the learner to impart entrepreneurial qualities and skills to give a chance to the learner to survive in the world of business. Albert, Sciascia and poli (2004) defined entrepreneurship education as the structured formal conveyance of entrepreneurial capabilities, which in return refers to the concepts, skills and mental awareness used by individuals during the process of starting and developing their growth-oriented ventures. Sexton and Smilor (1997) define entrepreneurship education as a formal structured instruction that conveys entrepreneurial knowledge and develops in students, focused awareness relating to opportunity, recognition and the creation of new ventures. Mauchi et al., (2011) sited in Jones and English (2004) the definition of entrepreneurship education as a process of providing individuals with the ability to recognize commercial opportunities and the knowledge, skills and attitudes to act on them. Therefore, entrepreneurship education can be seen as process of imparting learners with entrepreneurial knowledge, skills and attitudes through a formal structured instruction. A formal structured instruction is usually guided by 
well defined aims, goals and objectives of a specific program. Entrepreneurship education and training programmers are aimed directly at stimulating entrepreneurship which may be defined as independent small business ownership or the development of opportunity-seeking managers within companies Colton (1990).

The existence of a strong connection between education and entrepreneurial success has been well documented in academia.( Ascher 106.) Education plays an essential role is entrepreneurship by providing a wide range of skills necessary for opportunity identification, and the ability to establish a business, as well as efficiency of decision-making. All of these are crucial aspects of the entrepreneurial culture, as they have a direct impact on profitability, growth rates, job formation and value creation that businesses display. The availability of formal training, as well as the range of educational opportunities individuals benefit from prior to their engaging in entrepreneurial endeavor, can significantly enhance the efficiency of entrepreneurs, as well as their capacity to grow businesses and to create value within the market on which they operate. Furthermore, entrepreneurs who benefit from higher levels of educational are significantly more likely to innovate compared to entrepreneurs with little to no education. Innovation consists of the capacity to offer new products and services to consumers,( GEM ) and is thus crucial to the entrepreneurial process.

\section{Level of education in different country}

The average education level of women entrepreneurs differs from country to country. To compare countries, an average indicator was calculated weighting the three education levels: 1 for the low level, 2 for middle level and 3 for high level. Thus, an indicator value of 1 indicated that all entrepreneurs had attained pre-primary, primary and lower secondary education. An indicator value of 3 meant that all entrepreneurs had attained first and second stages of tertiary education. Data provided referred to the highest attained level achieved by an entrepreneur.

In 2012, women entrepreneurs in Europe-37 attained on average level 2.1 and men entrepreneurs level 1.9. In EU-28, the levels were 2.1 for women entrepreneurs and 2.0 for men entrepreneurs, indicating that women were slightly more highly educated than men entrepreneurs. The top five countries with the highest average education level of women entrepreneurs in 2012 were Estonia, Ireland, Belgium, Germany and Luxembourg, and with the lowest average education level were Turkey, Albania, Portugal, Romania and Croatia. The top five countries with the highest average education level of men entrepreneurs were Estonia, Germany, Luxembourg, Switzerland and Liechtenstein, and with the lowest were Turkey, Albania, Portugal and Croatia. In 2008, women entrepreneurs in Europe-37 attained level 2.0, and men entrepreneurs level 1.8. In EU-28, the levels attained were 2.0 for women entrepreneurs and 1.9 for men entrepreneurs. These figures indicate that women entrepreneurs attained a slightly higher education level than men entrepreneurs. Compared with 2008, the educational level of both women and men entrepreneurs in Europe-37 increased slightly in 2012 while educational level of entrepreneurs decreased slightly in EU28. (Statistical Data Women Entrepreneur Report) 


\section{Social Business}

In the modern world, scientific research on social business is gaining importance. Many of the world's most acute social problems have spread and enrooted so much that it cannot be solved by governments and traditional social sector organizations. The solution of these problems requires different approaches from both private and public sectors. A wide range of new models emerge from non-profit organizations supported entirely by donations and on the other hand, from purely profit-oriented businesses throughout the spectrum. When connecting business principles to social goals, emerging models build a bridge between social and private sectors.

The concept of social business of Professor Mohammad Yunus, Laureate of the Nobel Peace Prize is very urgent in the world and is increasing ever more. The basis of this concept is to build a world without poverty. Social business is a business model that meets the requirements of humanity. Social business operates in many ways, such as commercial businesses, but since social impact is the primary goal of this business, all profits need to be integrated into the business or used for the organization of a new public business. That is, energy is spent on human needs rather than profits, and social business gains with earned profit. Investor can only take startup capital. Management in social business is traditional and wages are paid referring to the market. Success is measured not by profits, but by the benefits generated.

The difference between social business and ordinary business is that social business is completely incompatible with the idea of personal gain in business (Kickul et al., 2012, pp. 457). However, unlike the enterprises that maximize profits, the main factor promoting social business entrepreneurs is solving social problems, so social business is created for the collective benefit of others. (Grove and Berg, 2014). Thus, the role and contribution of social business is essential for sustainable development because social business promotes human development through economic, environmental, and socially sustainable human choices (Humberg and Kleemann, 2014). Contrary to businesses willing to maximize profits, the focus is on solving a social problem, so a social business is being created for the collective benefit of others. (Grove and Berg, 2014). Development of social business plays an indispensable role in raising the level of wellbeing, leading to the elimination of unemployment and poverty reduction, the development of small and medium-sized businesses, and the long-term solution to social problems in society. Social Business promotes the development of vulnerable areas in the country (Fariz, Aytan and Ulkar, 2019)

\section{Impact of Education on Women's Sustainability in Social Business}

In Azerbaijan, $50.1 \%$ of the population is women and according to 2018, the number of eligible women to work is 3349.7 thousand people. Statistical indicators show that female entrepreneurship development indicators are different across the regions. While some regions have high entrepreneurial indicators, the highest indicator is in the capital, Baku. According to the State Statistical Committee of Azerbaijan, the number of women engaged in entrepreneurship in our country is 170934 people. 
There is no restriction or discrimination for women engaged in entrepreneurship in the legislation. Women can work with men in the same legal framework. The focus on women's entrepreneurship in the Strategic Roadmap of the United Nations is an indication that the acceleration of women entrepreneurship development is a priority for the state. The Strategic Roadmap envisages creating incentive mechanisms, developing information support, establishing business incubators, establishing women's entrepreneurship associations and professional organizations (Strategic Roadmap 2019) as an action plan for women entrepreneurship development.

\section{Analysis}

Hypothesis 1 Higher education level of female entrepreneurs operating in Azerbaijan has a direct impact on their self-esteem.

Hypothesis 2 Sustainable development of social business in Azerbaijan is directly related to education and information.

In 2019, a survey conducted by the author (Bayramova, 2019) conducted survey among 316 female entrepreneurs. Based on the responses of women entrepreneurs, 33 male, 27 full-aged, 160 female students and 96 masters / doctoral candidates were educated. At the same time, the following table was obtained based on survey results. Anova analysis, conducted among the questions of Education and Self-Confirmation, revealed that middle-income women entrepreneurs were less courageous than other women in the survey. The direct influence tion on working life shows that middle-income women face a problem of self-reliance in comparison with other women, which gives us more conclusions about educated women with Bachelor and Master / Doctoral degree programs.

Table 1: "Your education" and "Trust yourself" Anova analysis

I believe myself

\begin{tabular}{|l|l|l|l|l|l|}
\hline & Sum of Squares & Df & Mean Square & F & Sig. \\
\hline Between Groups &, 847 & 3 &, 282 & 1,368 &, 253 \\
\hline Within Groups & 64,353 & 312 &, 206 & & \\
\hline Total & 65,199 & 315 & & & \\
\hline
\end{tabular}

I believe myself

\begin{tabular}{|ll|l|l|}
\hline & & & Subset for alpha $=\mathbf{0 . 0 5}$ \\
& Your education? & $\mathbf{N}$ & $\mathbf{1}$ \\
\hline Turkey & Full middle & 27 & 1,1111 \\
HSD $^{\mathrm{a}, \mathrm{b}}$ & Secondary specialty & 33 & 1,1515 \\
& $\begin{array}{l}\text { Magister/Doctoral } \\
\text { studies }\end{array}$ & 96 & 1,2500 \\
& Bachelor & 160 & 1,2688 \\
& Sig. & &, 329 \\
\hline Scheffe $^{\mathrm{a}, \mathrm{b}}$ & Full middle & \\
& Secondary specialty \\
& Magister/ Doctoral studi & 27 & 1,1111 \\
& Bachelor & \\
Sig. & &
\end{tabular}




\begin{tabular}{ll|l|l}
$\begin{array}{l}\text { Secondary specialty } \\
\text { Magister/ Doctoral }\end{array}$ & 33 & 1,1515 \\
$\begin{array}{l}\text { studies } \\
\text { Bachelor }\end{array}$ & 96 & 1,2500 \\
Sig. & 160 & 1,2688 \\
& &, 414 \\
\hline
\end{tabular}

The first example of social business in Azerbaijan is "ABAD" (http://abad.gov.az/) created as a center for socially-oriented projects to support active participation of citizens in the socioeconomic development of the Republic of Azerbaijan and the development of small and medium-sized businesses and the formation of competitive households.

There are also examples of social business, such as small and medium-sized businesses, each of which has a social mission. While there are no statistical reports on social business in Azerbaijan, the majority of entrepreneurs engaged in social business in Azerbaijan have been identified as women during the scientific research conducted by the author (Zeynalova, 2019) in 2019.

In an interview with other respondent Sara Rajabli, founder of BUTA Art \& Sweets Social Business told that "I started to investigate this field after attending 2 Erasmus + trainings in Germany for 1 semester education and social entrepreneurship. I mainly worked with books, articles, and TEDx speeches, to master this field" and that this interest was created within the program outside the country. In the interview, other respondent, the first Azerbaijani social entrepreneur women, the founder of social platform Zarangiz Huseynova, name of which entered in the Forbes told that "I went to America, heard about social business, went through the program and realized that this is an ideal model for me."

In an interview with Nargiz Askerova, founder of the NEW HORIZONS social project told that "I started the project NEW HORIZONS when I was in Canada. And there were all the resources I needed. Because this field has been developed very much there. There it is thought at the state level that the development of entrepreneurship should be based namely on social entrepreneurship. When I was in Canada, while attending the "2018 DOT OTTAWA" program, this program was for young people who already had a social business plan and wanted to develop their idea throughout the program.

And as a resource, I have benefited from the resources of that "2018 DOT OTTAWA". At the same time, saying "I benefited from my network there", emphasized that social business opportunities are more extensive outside the country. At the same time, social business owners were interviewed. Most female entrepreneurs interviewed were informed about social work programs and courses outside the country. When it comes to the business activities of women engaged in social business in Azerbaijan, we see that education is an important factor in the sustainability of this field.

\section{Result and suggestion}

The participation of women involved in social-cultural, political, and intellectual change of the country in social business to contribute to the solution of society's problems is important 
for the rapid development of this process. Addressing of social business to a large number of social businesses and long term sustainability are related to education. Studies show that women with higher education in Azerbaijan are more self-confident than other women in entrepreneurial activity. Educated women start a step in social business as well as in all areas. The reason is that the educated woman is more informed and has a broader network.

The surveys suggest that information about social business in Azerbaijan are more accessible for women to refer to foreign country bases. Gaps in education in this area are one of the key factors that adversely affect the sustainable development of social business. Thus, the absence of the subject matter and the lack of funds in the Azerbaijani language in this field, as well as the lack of propaganda, prove that.

The study started with two hypotheses. The first hypothesis "The level of women entrepreneurs functioning in Azerbaijan has a direct impact on their self-esteem" is confirmed in Table 1 during the study. Hypothesis 2 "Sustainable development of social business in Azerbaijan is directly related to education and information" interviews have been confirmed by the hypothesis that female entrepreneurs dealing with social affairs in Azerbaijan are directed to this field through information and education.

Taking into account all this, the education level of women entrepreneurs should be improved in order to ensure sustainable development of social business in Azerbaijan, and the information should be accessible and accurate.

1. Regular investigations are to be carried out in relation to women entrepreneurship and reports are to be prepared.

2. Social science should be taught at universities.

3. Social business information should be accessible and from one center.

4. Preparation of social business resources in Azerbaijani language.

5. Samples of social business in the world should be applied to female entrepreneurs in Azerbaijan.

6. Establishing cooperation among women entrepreneurs and local women entrepreneurs engaged in successful social business in the world

7. Enhance educational work and increase the number of trainings in this area.

8. Providing funding for the best ideas and projects by the Government

9. Information about female entrepreneurs who develop social business through education should be disseminated through media (PR)

10. The women are to be inspired about the social business in solving international problems.

\section{REFERENCES}

[1] Ahmadov, F., \& Salmanova, M. (2013). Analyzing of Investment Strategies of Local Companies in Azerbaijan: Problems and Solutions. China-USA Business Review, 12(8).

[2] Ahmadov, F. (2018, November). Analysis of the application of social responsibility by domestic businesses in Azerbaijan and its influence on the competitiveness of the country. In Economic and Social Development (Book of Proceedings Vol. 2/4), 55th International Scientific Conference on Economic and Social (p. 706).

[3] Albert F. Sciascia S. and Poli A. (2004). Entrepreneurship Education: Notes on an Ongoing Debate. Proceedings of the 14th Annual Internet Conference, University of Napoli Federico II, Italy, 4-7 July. 
[4] Azərbaycan Respublikasının milli iqtisadiyyat perspektivi üzrə Strateji Yol Xəritəsi https://static.president.az/pdf/38542.pdf

[5] Brush, C. G., Bruin, A. \& Welter, F. (2009). A Gender-Aware Framework For Women's Entrepreneurship. International Journal of Gender and Entrepreneurship, 1(1):8-24. doi: $10.1108 / 17566260910942318$

[6] Dharmendran, A., "A Study on Women Entrepreneurship Development Through Self Help Group", Shanlax International Journal of Management, IV/1, 2016, s. 69-74

[7] Fariz Ahmadov, Aytan Huseynli and Ulkar Zeynalova "Comparative Analysis Of The Current Situation And Development Prospects Of The Former Soviet Union Republics In The Social Business" Economic and Social Development, p 1454-1462, Baku, 14-15 February 2019

[8] Grove,A. and Berg, G.A. (2014), Social Business: Defining and situating the concept, in the book of_Social Business: Theory, Practice, and Critical Perspectives', Springer.

[9] Humberg, K. and Kleemann, L. (2014), - Enhancing the contribution of social business to sustainable developmentl, Development Co-operation Report 2014: Mobilising Resources for Sustainable Development.

[10] Xavier, S.R., Kelley, D.J., Kew, J., Herrington, M. \& Vorderwülbecke, A.(2012) Global Entrepreneurship $\quad 2012$ Gonitor: Report. http://www.leo.itesm.mx/GEM/Reporte\%20Global\%202012.pdf

[11] Jones, C. and English, J. (2004). A contemporary approach to entrepreneurship education. Educ. Training, 46(8), 416-423.

[12] Kelley, D.(2011). Women's Entrepreneurship Around the World. Entrepreneurial Dynamics Conference Warsaw, Poland December 2011. http://www.parp.gov.pl/files/74/75/76/479/15332.pdf

[13] Kelley, D.J., Brush C.G., Greene, P.G.. \& Litovsky, Y. (2011). Global Entrepreneurship Monitor: 2010 Women's Report. http://www.gemconsortium.org/docs/download/768

[14] Kickul, J., Terjesen, S., Bacq, S. and Griffiths, M. (2012), -Social Business Education: An Interview with Nobel Laureate Muhammad Yunusll, Academy of Management Learning \& Education, 11(3): 453-462.

[15] Kolvalainen, A. \& Arenius, P. (2006). Country Report on Finland, in C. Brush, N. Carter, E. Gatewood et al. (eds) The Diana Project International: Growth Oriented Women Entrepreneurs and their Businesses: A Global Research Perspective (New Horizons in Entrepreneurship).

[16] Littlejohn, V., (2006). "Women Entrepreneurship: An İmportant İssue for Global Policy Agenda". OECD\# SME and Entrepreneurship Outlook 2005 (p. 107-118). Paris: OECD Publishing

[17] Mauchi ET AL., (2011). Entrepreneurship education lessons: a case of Zimbabwean tertiary education institutions. Educational Research, 2(7), 1306-1311.

[18] Neergaard, H. (2006). Country Report on Denmark, in C. Brush, N. Carter, E. Gatewood et al. (eds) The Diana Project International: Growth Oriented Women Entrepreneurs and their Businesses: A Global Research Perspective (New Horizons in Entrepreneurship).

[19] Nurkhodzha Akbulaev, Ilkin Mammadov, Samir Shahbazli , "Accounting Education in the Universities and Structuring According to the Expectations of the Business World," Universal Journal of Accounting and Finance, Vol. 9,

[20] No. 1, pp. 130-137, 2021. DOI: 10.13189/ujaf.2021.090114.

[21] Pue Ho Chu, P(2004) The Making of Women Entrepreneurs in Hong Kong. Aberdeen, Hong Kong: Hong Kong University Press.

[22] Rosenberg, Michelle (2007); Inspirinig Women: How Real Women Succeed in Business, Surrey: Crimson Publishing, http://www.amazon.co.uk/InspiringWomen-EntrepreneursSucceed-Business/dp/1854584103\#reader_1854584103

[23] Sexton, D. and Smilor, R. (1997). Entrepreneurship. Upstart Publishing Company. Chicago Illinois. Van de Kuip. I. and Vernheul, I (2003). Early Development of Entrepreneurial Qualities: the role of initial education. Centre for Advanced Small Business Economics Erasmus University Rotterdam. 
[24] State of Women-Owned Businesses Report 2017

https://about.americanexpress.com/sites/americanexpress.newshq.businesswire.com/files/do c_library/file/2017_SWOB_Report_-FINAL.pdf

[25] Ulkar Bayramova (2019) "Kiçik və orta sahibkarlıqda qadın sahibkarlıq: Bakı nümunəsi "

[26] Ulkar Zeynalova (2019) "Sosial biznesin Azərbaycanda inkişaf perspektivləri"

[27] Vita L.D., Mari M. \& Poggesi S. (2014). Women Entrepreneurs in and from Developing Countries: Evidences from the Literature. European Management Journal, 32:451-460. doi:10.1016/j.emj.2013.07.009

[28] Women Business Owner Statistics 2017 https://www.nawbo.org/resources/women-businessowner-statistics 